\title{
CAEP 2015 Academic Symposium: Leadership within the emergency medicine academic community and beyond
}

Doug Sinclair, MD*; James R. Worthington, $\mathrm{MD}^{\dagger}$; Gary Joubert, MD; Brian R. Holroyd, MD, MBA ${ }^{\S}$; James Stempien, MD ; Eric Letovsky, MD**; Tim Rutledge, MD**+†; Constance LeBlanc, MD, MAEd ${ }^{\ddagger \neq}$; Carrol Pitters, MBBS ${ }^{\S \S}$; Andrew McCallum, MD ${ }^{\text {If } ; ~ B r e n d a n ~ C a r r, ~ M D, ~ M B A * * * * ; ~ R o c c o ~ G e r a c e, ~}$ MD $^{\dagger+t}$; lan G. Stiell, MD, MSc ${ }^{\dagger}$; Jennifer D. Artz, $\mathrm{PhD}^{\ddagger \neq \neq} ;$ Jim Christenson, $\mathrm{MD}^{\S \S \S}$

\section{ABSTRACT}

Objectives: A panel of emergency medicine (EM) leaders endeavoured to define the key elements of leadership and its models, as well as to formulate consensus recommendations to build and strengthen academic leadership in the Canadian EM community in the areas of mentorship, education, and resources.

Methods: The expert panel comprised EM leaders from across Canada and met regularly by teleconference over the course of 9 months. From the breadth of backgrounds and experience, as well as a literature review and the development of a leadership video series, broad themes for recommendations around the building and strengthening of EM leadership were presented at the CAEP 2015 Academic Symposium held in Edmonton, Alberta. Feedback from the attendees (about 80 emergency physicians interested in leadership) was sought. Subsequently, draft recommendations were developed by the panel through attendee feedback, further review of the leadership video series, and expert opinion. The recommendations were distributed to the CAEP Academic Section for further feedback and updated by consensus of the expert panel.

Results: The methods informed the panel who framed recommendations around four themes: 1) leadership preparation and training, 2) self-reflection/emotional intelligence, 3) academic leadership skills, and 4) gender balance in academic EM leadership. The recommendations aimed to support and nurture the next generation of academic EM leaders in Canada and included leadership mentors, availability of formal educational courses/programs in leadership, self-directed education of aspiring leaders, creation of a
Canadian subgroup with the AACEM/SAEM Chair Development Program, and gender balance in leadership roles.

Conclusions: These recommendations serve as a roadmap for all EM leaders (and aspiring leaders) to build on their success, inspire their colleagues, and foster the next generation of Canadian EM academic leaders.

\section{RÉSUMÉ}

Objectif: Un groupe de chefs de file en médecine d'urgence (MU) s'est employé à définir les principaux éléments du pouvoir d'influence et de ses modèles, en plus de formuler des recommandations consensuelles visant à établir et à renforcer ce pouvoir universitaire au sein de la communauté intéressée par la médecine d'urgence au Canada dans les domaines du mentorat, de la formation et des ressources.

Méthode: Le groupe d'experts se composait de chefs de file en MU qui provenaient de toutes les régions du Canada, et il a tenu régulièrement des réunions par téléconférence sur une période de neuf mois. S'appuyant sur la diversité de leur bagage de connaissances et de leur expérience ainsi que sur l'examen de la documentation et sur l'élaboration d'une série de vidéos sur le pouvoir d'influence, les membres ont présenté les grands thèmes autour desquels s'articuleraient les recommandations sur l'édification et le renforcement de ce pouvoir en $\mathrm{MU}$, à l'occasion du symposium sur les affaires universitaires de I'ACMU de 2015, qui s'est tenu à Edmonton, en Alberta. On a demandé aux participants (environ 80 médecins d'urgence intéressés par le pouvoir d'influence) de faire part de leurs observations sur le sujet. Le groupe d'experts a, par la suite, élaboré des recommandations préliminaires en tenant compte des observations des participants, d'un nouvel examen

From the *St. Michael's Hospital, Toronto, ON; †Department of Emergency Medicine, University of Ottawa/Ottawa Hospital Research Institute, Ottawa, ON; ¥Pediatric Emergency Medicine, Department of Pediatrics and Medicine, Western University, London, ON; §Department of Emergency Medicine, University of Alberta, Edmonton, AB; IDepartment of Emergency Medicine, University of Saskatchewan, Saskatoon, SK; **Division of Emergency Medicine, Department of Family and Community Medicine, University of Toronto, Toronto, ON; ††North York General Hospital, Toronto, ON; ¥¥Faculty of Medicine, Dalhousie University, Clinical Research Centre, Halifax, NS; §§Department of Pediatric Medical Education, University of Ottawa/Children's Hospital of Eastern Ontario (CHEO), Ottawa, ON; T†Ornge, Mississauga, ON; ***Vancouver Island Health Authority, Victoria, BC; †††College of Physicians and Surgeons of Ontario, Toronto, ON; ¥¥¥Canadian Association of Emergency Physicians, Ottawa, ON; and §§§Department of Emergency Medicine, University of British Columbia, JPPN, Vancouver General Hospital, Vancouver, BC.

Correspondence to: Dr. Douglas Sinclair, St. Michael's Hospital, 30 Bond Street, Toronto, ON M5B 2Y9; Email: sinclaird@smh.ca. 
de la série de vidéos sur le pouvoir d'influence et de l'opinion $d^{\prime}$ experts. Après cela, les recommandations ont été transmises à la division des affaires universitaires de I'ACMU pour d'autres observations, puis ont finalement été mises à jour par le groupe d'experts après l'atteinte d'un consensus.

Résultats: Le groupe, éclairé par la démarche, a formulé des recommandations sur quatre grands thèmes : 1) la préparation au pouvoir d'influence et la formation; 2) l'autoréflexion et l'intelligence émotionnelle; 3 ) les qualités de chef en milieu universitaire; et 4) l'équilibre dans la représentation des sexes au sein de la sphère d'influence en $\mathrm{MU}$, dans le milieu universitaire. Les recommandations visaient à soutenir et à encourager la nouvelle génération de chefs de file en $M U$, dans le milieu universitaire, au Canada, et elles portaient sur le mentorat en matière de pouvoir d'influence, l'offre de cours de formation et de programmes structurés dans le domaine, la formation autodirigée de chefs de file potentiels, la formation d'un sous-groupe canadien rattaché à I'AACEM/ SAEM Chair Development Program et la représentation équilibrée des sexes dans les rôles de direction.

Conclusions: Ces recommandations servent de feuille de route à tous les chefs de file en MU (et aux chefs potentiels) afin qu'ils misent sur leur réussite, qu'ils soient source d'inspiration pour leurs collègues et qu'ils insufflent la confiance à la nouvelle génération de chefs de file en MU au Canada.

Keywords: leadership, emergency medicine, mentorship, education, training

\section{INTRODUCTION}

The Academic Section of the Canadian Association of Emergency Physicians (CAEP) was officially formed in 2013 and consists of working groups on education scholarship, research, and leadership. Each working group was charged with presenting a symposium at a CAEP Annual Scientific Meeting and publishing their findings and recommendations. ${ }^{1-7}$ For CAEP 2015, the Leadership Working Group formed three panels on leadership, governance, and funding, to articulate the issues, structure recommendations, and plan interactive 1-hour symposia during the CAEP 2015 annual meeting. The purpose of the leadership panel was to describe the key elements of leadership and develop recommendations to strengthen leadership for academic activity in emergency medicine (EM). At the symposium, a framework for leadership and videos of opinions of well-known, successful leaders in EM was presented. This paper is meant to offer recommendations, stimulate debate, and ultimately strengthen the academic output in EM in medical schools across Canada.

In the challenging, chaotic environment of EM, a deliberate, thoughtful approach to leadership skill development is essential for success. Academic medicine provides its own dimension to leadership, because university culture can be very distinct from that of the health system. Academic medical leaders find themselves at the point of intersection between these two systems, systems that may frequently have conflicting priorities while relying on a common resource base.

Many leaders in EM have learned their leadership skills through experience and have extensive tacit knowledge with respect to successful strategies.
Traditionally, EM leaders have thought about specific tasks and roles as leadership and not understood or been able to articulate the more important "soft skills" of effective leaders. In a recent article defining education for EM leaders, only 5 of 64 competencies could be categorized as "leadership skills" with the vast majority being managerial tasks, such as managing the schedule, developing the disaster plan, and so forth. ${ }^{8}$

The goal of the leadership panel was to define the key components required for academic EM leaders, find the most suitable leadership model for academics, if one existed, and make recommendations to enhance and nurture leadership skill development in Canada.

\section{Methodology: Review of current leadership resources}

Eight established medical leaders were identified from across Canada for their contributions to the EM community and were asked to form a leadership panel. The panel met by teleconference four times and was supported by the Academic Section of CAEP. All members reviewed the literature and discussed individual leadership experiences to identify core leadership skills, models, resources, and challenges.

The panel developed a list of eight questions in four categories designed to engage an audience and develop a framework to discuss leadership and leadership models (Figure 1). The questions were pilot-tested among the panel members and updated for focus and clarity. Six medical leaders, who originally worked within EM but had moved on to leadership positions in health care outside of EM, were invited to participate in the leadership video series. The interviewees submitted videos (see supplementary material) that were reviewed and edited from 107 to 24 minutes for highlights that 


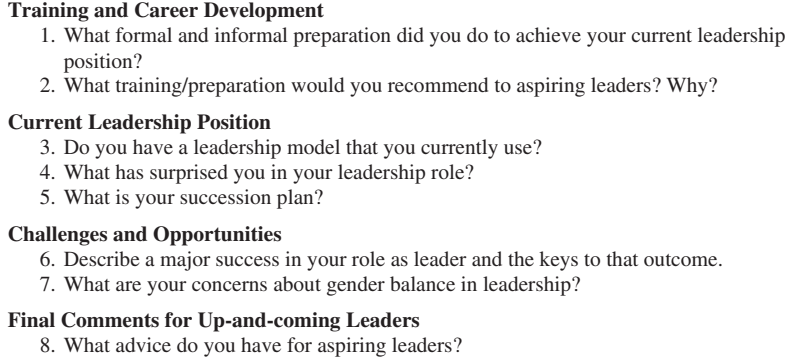

Figure 1. Structured questions for the leadership video series.

played during an hour-long session at the Academic Symposium, held on May 30, 2015, in Edmonton, Alberta. The videos served as rich data sources and assisted the panel in generating an active discussion at the Academic Symposium. Feedback collected at the symposium and further discussion by the panel culminated in six recommendations. The recommendations were distributed to the Academic Section in August 2015 for further feedback and updated by panel consensus. During the development of the recommendations, the panel attempted to be as specific as possible, while recognizing that the academic environment is varied at the 17 medical faculties across Canada.

\section{Review of leadership models}

After a literature search and discussion by the leadership knowledge of this group, the panel determined that there were two leadership models in health care worth the consideration: 1) the National Health Service (NHS) Leadership Program ${ }^{9}$ in the United Kingdom and 2) LEADS leadership capabilities framework ${ }^{10}$ used by a number of Canadian hospitals and endorsed by the Canadian Medical Association (CMA).

The panel reviewed in detail both the NHS and LEADS program. The NHS leadership program was developed in response to failures in leadership at many levels in the NHS. The program is a generic health care model and competency-based. For each dimension, various levels of competencies are defined: essential/ proficient/strong/exemplary. Its nine dimensions of leadership are inspiring shared purpose, leading with care, evaluating information, connecting service, sharing the vision, engaging the team, holding to account, developing capability, and influencing for results (Table 1). Focused on high-level leadership skills, this program is appealing. However, the panel considered that
Table 1. NHS Leadership Program's nine dimensions of leadership

1. Inspiring shared purpose

2. Leading with care

3. Evaluating information

4. Connecting service

5. Sharing the vision

6. Engaging the team

7. Holding to account

8. Developing capability

9. Influencing for results

its recommendation would face challenges on two fronts: adaptation to a Canadian context and obtaining engagement from the academic EM community.

The second model reviewed was the LEADS leadership capabilities framework. LEADS stands for "lead self, engage others, achieve results, develop coalition, and systems transformation." The LEADS framework was developed through a collaborative partnership between the Canadian College of Health Leaders, the Canadian Health Leaders Network (CHLnet), and Royal Roads University, in response to the growing interest across Canada in the adoption, integration, and sustainability of a common leadership capabilities framework. It has been endorsed by the CMA and incorporated into many leadership courses offered through the Physician Management Institute (PMI). LEADS has also been adopted as the evaluation framework for the Canadian Certified Physician Executive credential offered jointly by the CMA and Canadian Society for Physician Leadership and is used with increasing frequency by health organizations across Canada in leadership performance evaluation. Although its utility as a standardized leadership capability framework has been established, LEADS provides little insight into what approaches that leaders may take to achieve the desired capabilities. In practice, most leaders apply multiple strategies or models while trying to achieve the broad competencies outlined in LEADS. In light of this, the panel was concerned that the adoption of LEADS, in isolation, may not strengthen leadership in academic EM in Canada.

\section{Review of educational resources for leadership development}

There are a number of short-term and long-term education offerings in leadership/management at many 


\begin{tabular}{|c|c|}
\hline Course/Series & URL \\
\hline Academic Leadership Development Program (UBC) & http://aldp.ubc.ca/ \\
\hline $\begin{array}{l}\text { CAME's (Canadian Association for Medical Education) Canadian } \\
\text { Leadership Institute for Medical Education (CLIME) }\end{array}$ & http://www.came-acem.ca/mededconferences_clime_en.php \\
\hline $\begin{array}{l}\text { Leadership Development for Chairs and Chair-like Academic Leaders } \\
\text { (University of Alberta) }\end{array}$ & $\begin{array}{l}\text { http://www.hrs.ualberta.ca/en/Learning/Programs/Leadership/ } \\
\text { LeadershipDevelopmentforChairs.aspx }\end{array}$ \\
\hline PMI Physician Leadership Courses & $\begin{array}{l}\text { https://www.cma.ca/En/Pages/pmi-physician-leadership- } \\
\text { courses.aspx }\end{array}$ \\
\hline Queen's University School of Business: Executive Education: Leadership & $\begin{array}{l}\text { http://business.queensu.ca/executiveeducation/programs/ } \\
\text { leadership.php }\end{array}$ \\
\hline $\begin{array}{l}\text { Society of Academic Continuing Medical Education (SACME) } \\
\text { [Leadership Course for CME Deans] }\end{array}$ & http://www.sacme.org/ \\
\hline
\end{tabular}

universities in Canada. In most academic centres, both the Master of Health Administration (MHA) and/or the Master of Business Administration (MBA) with an emphasis in health are available, with many offering an executive option for learning while employed full-time. Through the PMI, the CMA runs 2-day courses on various aspects of leadership. These courses receive very positive evaluations and are useful to physician leaders in practice. The CMA also offers a Physician Leadership course, which uses the LEADS framework. The panel cannot recommend any single leadership model or course; however, there was strong endorsement for individuals planning an administrative career path to seek additional training in the field. The panel has developed a partial listing of leadership courses in Canada relevant to physicians (Table 2). Reading about leadership (including models, strategies, and practical guides) emerged as an important means of education, and a list of recommended reading was compiled by collating all of the suggestions (Table 3).

\section{Other key factors identified in leadership development}

During the process of discussing leadership models and skill sets, it was discovered that each panel member has had a very different leadership journey with both formal and informal education supporting and developing leadership skills. There are lessons in each of the leadership paths that were taken. ${ }^{11}$ The panel also recognized a significant gender issue in academic EM and felt this was important to incorporate into the recommendations.

\section{RECOMMENDATIONS}

Leadership theme 1: Leadership preparation and training

Recommendation 1: The CAEP Academic Section should maintain an up-to-date listing of leadership education courses/programs on the CAEP website without specific endorsement of any particular program.

Recommendation 2: The CAEP Academic Section should develop a leadership mentorship framework and offer formal mentorships to any interested academic EM leader.

Among the panelists and expert interviewees, there were two MBA graduates but no MHA graduates. Opinions were mixed on the value of these types of formal programs and designations. All panelists agreed that in order to be an effective leader, one must extensively read the leadership literature to understand leadership styles to best develop one's own skills. It was felt that a working knowledge of management fundamentals, leadership skills, their language, and other perspectives were essential to interact effectively at a high level. We agreed that these skills may be assimilated more easily through formal programs. Many of the interviewees made suggestions with respect to useful books or publications, such as the Harvard Business Review (see Table 3). As far as formal educational courses, there was general agreement on the value of the CMA PMI courses, but no specific endorsement of a program, due to the large number and continued evolution of these programs. In planning programs for knowledge and skills development, it is 
Table 3. Reading list for those aspiring to leadership roles as recommended by the 2015 Academic Symposium panelists

Author

Annis, Barbara

Atchison, Tom

Barash, David P., and Lipton, Judith E.

Blanchard, Ken, and Spencer, Johnson

Bryson, John M.

Bungay, Stephen

Cain, Susan

Cameron, Kim

Carnegie, Dale

Carnegie, Dale

Christensen, Clayton M.

Collins, Jim

Covey, Stephen

Drucker, Peter F.

Fisher, Roger; Ury, William L.; and Patton, Bruce

Gardner, Howard E.

Gawande, Atul

Gladwell, Malcolm

Goleman, Daniel; Boyatzis, Richard; and McKee, Annie

Harvard Business Review; Drucker, Peter D.; Christensen,

Clayton M.; Goleman, Daniel; and Porter, Michael E.

Heath, Chip, and Heath, Dan

James, Aaron

Kotter, John P.

Kouzes, James M., and Posner, Barry Z.

Kouzes, James M., and Posner, Barry Z.

Kuhn, Thomas S., and Hacking I.

Laloux, Frederic, and Wilber, Ken

Lencioni, Patrick

Maxwell, John

Maxwell, John

Maxwell, John

Patterson, Kerry; Grenny, Joseph; and Switzler, Al

Patterson, Kerry; Grenny, Joseph; McMillan, Ron; and Switzler, Al

Pink, Daniel $\mathrm{H}$.

Rath, Tom, and Conchie, Barry

RoAne, Susan

Rutledge, Tim, and Sinclair, Doug

Sandberg, Sheryl
Title/Series

Gender Intelligence: Breakthrough Strategies for Increasing Diversity and Improving Your Bottom Line

Followership: A Practical Guide to Aligning Leaders and Followers

The Gender Gap: The Biology of Male-Female Differences

The One Minute Manager

Strategic Planning for Public and Nonprofit Organizations: A Guide to Strengthening and Sustaining Organizational Achievement

The Art of Action: How Leaders Close the Gaps between Plans, Actions, and Results

Quiet: The Power of Introverts in a World That Can't Stop Talking

Positive Leadership: Strategies for Extraordinary Performance

How to Win Friends and Influence People

How to Win Friends and Influence People in the Digital Age

The Innovator's Dilemma: The Revolutionary Book That Will Change the Way You Do Business

Good To Great: Why Some Companies Make the Leap...And Others Don't

Seven Habits of Highly Effective People

The Essential Drucker: The Best of Sixty Years of Peter Drucker's Essential

Writings on Management (Collins Business Essentials)

Getting to Yes: Negotiating Agreement Without Giving In

Leading Minds: An Anatomy of Leadership

The Checklist Manifesto: How to Get Things Right

Blink: The Power of Thinking Without Thinking

Primal Leadership, Learning to Lead with Emotional Intelligence

HBR's 10 Must Reads Boxed Set (6 Books)

Switch: How to Change Things When Change Is Hard

Assholes: A Theory

Leading Change

The Truth about Leadership: The No-fads, Heart-of-the-Matter Facts

You Need to Know

The Leadership Challenge: How to Make Extraordinary Things Happen in

Organizations

The Structure of Scientific Revolutions

Reinventing Organizations: A Guide to Creating Organizations Inspired by the Next Stage of Human Consciousness

Death by Meeting: A Leadership Fable...About Solving the Most Painful Problem in Business

The 21 Irrefutable Laws of Leadership: Follow Them and People Will Follow You

Leadership 101: What Every Leader Needs to Know

Good Leaders Ask Great Questions: Your Foundation for Successful Leadership

Crucial Confrontations: Tools for talking about broken promises, violated expectations, and bad behavior

Crucial Conversations: Tools for Talking When Stakes Are High

Drive: The Surprising Truth About What Motivates Us

Strengths-Based Leadership

How to Work a Room, 25th Anniversary Edition: The Ultimate Guide to Making

Lasting Connections - In Person and Online

Your Profession Needs You (Lessons in Medical Leadership)

Lean In: Women, Work and the Will To Lead 


\begin{tabular}{ll} 
Table 3. (Continued) & \\
\hline Author & Title/Series \\
\hline $\begin{array}{l}\text { Senge, Peter M. } \\
\text { Sinek, Simon }\end{array}$ & The Fifth Discipline: The Art \& Practice of The Learning Organization \\
Sinek, Simon & Start with Why: How Great Leaders Inspire Everyone to Take Action \\
Sutton, Robert I. & Leaders Eat Last: Why Some Teams Pull Together and Others Don't \\
& The No Asshole Rule: Building a Civilized Workplace and Surviving One \\
Templar, Richard & That Isn't \\
Waitkins, Michael D. & The Rules of Work, Expanded Edition: A Definitive Code for Personal Success \\
Wall Street Journal & The First 90 Days: Proven Strategies for Getting Up to Speed Faster and \\
Zimmerman, Brenda; Lindberg, Curt; and Plsek, Paul & Smarter, Updated and Expanded \\
& Management Series \\
& Edgeware: Lessons from Complexity Science for Health Care Leaders
\end{tabular}

worth pointing out that leadership and management are distinct, although interrelated, disciplines. Not all good leaders are good managers, and vice versa. Whereas leadership is about vision, strategy, and inspiring people, management is about getting things done. Management skills include planning, organizing, setting SMART goals (goals that are specific, measurable, achievable, relevant, and time-bound), monitoring progress with indicators, and taking corrective actions when necessary. Management also involves managing resources, which often includes financial resources. Most physicians have little training in financial management, yet financial acumen is highly valuable to those who take on leadership roles that involve managing budgets. There are countless courses available to develop the various management skills.

The importance of getting involved in task forces or committees at an early stage of one's career was emphasized. Starting small was a focus mentioned by both the video interviewees and the panelists. This approach allows an aspiring leader to learn from senior leaders in a safe environment, demonstrate interest, and develop mentorship relationships. These opportunities often led to further, more formal roles. All of the panelists and interviewees emphasized the importance of mentorship, both formal and informal. Many of these experienced leaders only realized the importance of mentorship later in their careers and, upon reflection, recognized that they had informal mentors that they could have used more extensively in their leadership journey. Many universities now recommend formal mentors for all new faculty members and have a template to be signed off by the mentor and mentee to guide this process.

\section{Leadership theme 2: Self-reflection/emotional intelligence}

All of the panelists and external interviewees emphasized the importance of self-reflection and understanding their personal values, strengths, and weaknesses, as key criteria to being an effective leader. All had anecdotes of leaders with excellent academic credentials who failed at leadership due to poor communication skills and limited emotional intelligence. Many new leaders in medicine focus on the management aspects and neglect the leadership component of their roles.

A number of strategies are helpful to address this leadership theme, including focused reading, leadership workshops, feedback from mentors, personality assessment tools, 360-degree feedback, and executive coaching. Among other self-directed educational opportunities, (aspiring) academic leaders should consider coaching and formal mentorship as key components of their personal leadership development while they familiarize themselves with the relevant policies and procedures (e.g., promotion) at their universities (Recommendation 3).

\section{Leadership theme 3: Academic leadership skills}

Recommendation 3: Aspiring leaders should direct their careers by educating themselves about their own strengths and weaknesses, finding opportunities to learn/improve, learning about the promotion policies, as well as understanding how to navigate the decision-making policies affecting EM units/departments in their university. A local mentor may be an asset in these aspects of leadership development. 
Recommendation 4: The CAEP Academic Section should forge a relationship and develop a subgroup of the AACEM/SAEM Chair Development Program to meet the needs of Canadian EM department chairs.

There are unique leadership skills required of an academic leader due to their extensive interaction with university structures and processes. Most EM leaders are familiar with hospital and health care system structures, while their knowledge of academic promotion criteria, faculty appointment requirements, and university decision-making, and funding structures may be limited. The panel felt that a specific recommendation for skills development and content knowledge was important to address this specific leadership competency.

Individuals interested in a career path in academic EM leadership must develop a good understanding of the university environment and the varied interactions that an academic program requires to flourish. Within a medical faculty, these include undergraduate and postgraduate medical education programs, research programs, as well as faculty governance structures, budgeting, and decision-making processes. Junior faculty should be encouraged to participate in key faculty committees in these various areas, because this exposure provides essential learning opportunities.

As an academic leader in EM, an individual will be responsible for representing the institution's program in key processes within the faculty and university. For example, an academic chair in EM must be knowledgeable in the specifics of the promotion and tenure review processes to facilitate appropriate mentoring and developmental steps for junior faculty, to guide development of documentation to support an individuals' promotion application, and to navigate the nuances of the formal review processes to provide the best chance for a successful outcome. A functional knowledge of the academic institution's policies, procedures, and guidelines is essential to success as an academic leader.

There is a variety of formal academic leadership development programs available. Many Canadian universities have formal leadership development programs available to their faculty (e.g., at the University of Alberta $^{12}$ and University of British Columbia ${ }^{13}$ ). The Association of Academic Chairs in Emergency Medicine (AACEM) offers a Chair Development Program. ${ }^{14}$ The Association of American Medical Colleges Leadership Development Series offers a variety of educational options. ${ }^{15}$ Informal academic mentoring opportunities are also worthwhile. Interactions with academic EM chairs and leaders offer chances to learn from others' experience. The AACEM offers an online forum for relevant discussions amongst members and an annual meeting highlighting a variety of relevant topics. ${ }^{16}$

The AACEM ${ }^{14}$ (which is a concomitant committee of SAEM) is highly valued by its members and was recommended by Academic Symposium speakers who are active members. Therefore, the panel recommends the creation of a Canadian Section of Academic Chairs that would develop a liaison with the AACEM over time.

\section{Leadership theme 4: Gender balance in academic EM leadership}

Recommendation 5: The CAEP Academic Section should develop a plan to improve gender balance in academic EM leadership across Canada. This could begin with surveying members to document the numbers of women in junior and senior leadership positions and what they perceive as the barriers and facilitators to entering and continuing in leadership roles. Universities should ensure that women have ample opportunity to participate in leadership training.

The panelists and interviewees were concerned with respect to the limited number of female academic EM leaders. With the evolving demographic of EM physicians ${ }^{17}$ and the changing work-life balance across generations, ${ }^{18}$ leadership development in both sexes will be increasingly important. This issue, of course, is not unique to EM and exists in other leadership areas both inside and outside of medicine. Nonetheless, women have been shown to be as competent as men as business leaders, and to excel in many of the qualities required of a leader - notably taking initiative, displaying integrity, driving for change, and so forth. ${ }^{19}$ Although progress has been made, growth in the numbers of women leaders at the higher ranks has been slow. The panel noted through their own experience that only a small portion of leadership positions in EM are held by women. For example, there are currently only two female department/division/section heads in academic EM in Canada. Now that many medical schools admit more women than men and there are increasing numbers of women in EM, it would be desirable to work towards a greater gender balance among EM leaders. 
While a gender balance could be achieved in time as growing numbers of women reach the stage of becoming leaders, the panel was concerned that this may not necessarily follow. More women than men appear not to aspire to a leadership role. In part, this is because women in mid-career often feel caught in the sandwich generation, caring for children and for aging parents and therefore unable to commit the time that it takes to be a successful leader. In part, it may also be because of a perception that leadership involves typically male behaviors, and the lack of female role models forms a selffulfilling prophecy and makes it hard to see themselves in the role. They may not have built the same networks of support that their male colleagues have, and there is a perception that hiring committees favor men. ${ }^{20}$

The panel felt that the leadership skill set would be enriched with a better gender balance. A challenge here is the paucity of female mentors to promote early development in young female leaders. Younger generations of EM physicians seeking greater work-life balance may serve to recalibrate this imbalance. The issue of gender balance must be addressed.

\section{Advice for future EM leaders}

\section{Recommendation 6: The CAEP annual meeting should offer an annual leadership track covering pathways to leadership in EM and developing a strong national mentorship network. Topic selec- tion should be tied to a needs assessment drawn from engaged leaders and leaders in development.}

The final question for the panel and interviewees was on advice for future leaders. Universally, the advice was positive. Leadership is personally rewarding, and EM leaders can contribute very significantly to both improving health care systems and the advancement of knowledge. An annual track at the CAEP conference is recommended so that all new and experienced leaders can learn from their EM colleagues.

\section{CONCLUSION}

The panel is optimistic about the future of academic EM leadership in Canada and recognizes plenty of young talent. It is hoped that current leaders will endeavour to further inspire and mentor the next generation of EM leaders. The panel feels strongly that the recommendations provided herein will allow the EM community within Canada to reach its full potential. The Leadership Working Group of the CAEP Academic Section will be addressing each of these recommendations over the next few years and will present an update at its next Academic Leadership Symposium to be held in 2018.

Acknowledgement: The authors thank Kelly Wyatt for managing the entire video series production from initial instructions to final editing, and her administrative support throughout the development of these recommendations.

Competing interests: None declared.

\section{SUPPLEMENTARY MATERIAL}

To view supplementary material for this article, please visit https://vimeo.com/144135835

\section{REFERENCES}

1. Sherbino J, van Melle E, Bandiera G, et al. Education scholarship in emergency medicine part 1: innovating and improving teaching and learning. C7EM 2014;16(Suppl 1):S1-5.

2. Bandiera G, LeBlanc C, Regehr G, et al. Education scholarship in emergency medicine part 2: supporting and developing scholars. C7EM 2014;16(Suppl 1):S6-12.

3. Bhanji F, Cheng A, Frank JR, et al. Education scholarship in emergency medicine part 3: a 'how-to' guide. CFEM 2014;16(Suppl 1):S13-8.

4. Stiell IG, Artz JD, Perry J, et al. Executive summary of the CAEP 2014 Academic Symposium: "How to make research succeed in your department." CFEM 2015;17(3):328-33.

5. Calder LA, Abu-Laban RB, Artz JD, et al. CAEP 2014 Academic Symposium: "How to make research succeed in your department: Promoting excellence in Canadian emergency medicine resident research." CFEM 2015;17(5):591-9.

6. Perry JJ, Snider CE, Artz JD, et al. CAEP 2014 Academic Symposium: "How to make research succeed in your emergency department: how to develop and train career researchers in emergency medicine." CFEM 2015;17(3):334-43.

7. Vaillancourt C, Rowe BH, Artz JD, et al. CAEP 2014 Academic Symposium: "How to make research succeed in your department: How to fund your research program". C7EM 2015;17(4):453-61.

8. Thoma B, Poitras J, Penciner R, et al. Administration and leadership competencies: establishment of a national consensus for emergency medicine. CFEM 2015;17(2):107-14.

9. National Health Service. NHS Leadership Academy: programmes for every level of leadership responsibility. Available at: http://www.leadershipacademy.nhs.uk/programmes/.

10. Canadian College of Health Leaders. LEADS Collaborative: LEADS in a caring environmental framework. Available at: http://www.leadersforlife.ca/site/framework?nav=02.

11. Rutledge T, Sinclair D. Your profession needs you (lessons in medical leadership). CFEM 2013;15(2):67-72.

12. University of Alberta - Human Resource Services. Leadership development for chairs and chair-like academic leaders. 
Available at: http://www.hrs.ualberta.ca/en/Learning/ Programs/Leadership/LeadershipDevelopmentforChairs.aspx.

13. The University of British Columbia. Academic leadership development program. Available at: http://aldp.ubc.ca/.

14. Society of Academic Emergency Medicine. Chair development program. Available at: http://www.saem.org/education/ chair-development-program.

15. Assocation of American Medical Colleges (AAMC). Leadership development series - member center. Available at: https://www.aamc.org/members/leadership/.

16. Society for Academic Emergency Medicine (SAEM). AACEM - Association of Academic Chairs of Emergency Medicine: Mission statement and membership. Available at: http://www.saem.org/membership/aacem.
17. National Physician Survey. 2013 Survey. Available at: http:// nationalphysiciansurvey.ca/surveys/2013-survey/.

18. Twenge JM, Campbell SM, Hoffman BJ, et al. Generational differences in work values: leisure and extrinsic values increasing, social and intrinsic values decreasing. 7 Manag 2010;36(5):1117-42, doi:10.1177/0149206309352246.

19. Sherwin B. Why women are more effective leaders than men. Business Insider; 24 January 2014. Available at: http:// www.businessinsider.com/study-women-are-better-leaders2014-1.

20. Sherwin B. Why women vanish as they move up the career ladder. Business Insider; 27 January 2014. Available at: http:// www.businessinsider.com/women-and-career-advancementleadership-2014-1. 